\title{
The role of maternal echocardiography and uterine artery Doppler at 11-14 weeks in the prediction of pre-eclampsia in nulliparous women
}

\author{
Dipak K. Sah ${ }^{1 *}$, Farzana Deeba ${ }^{2}$, Saleha B. Chowdhury ${ }^{3}$
}

\author{
${ }^{1}$ Janaki Medical College and Teaching Hospital, Janakpur, Nepal \\ ${ }^{2}$ Department of Reproductive Endocrinology and Infertility, ${ }^{3}$ Department of Obstetrics and Gynecology, Bangabandhu \\ Sheikh Mujib Medical University Hospital, Dhaka, Bangladesh
}

Received: 08 December 2021

Revised: 21 December 2021

Accepted: 22 December 2021

\author{
*Correspondence: \\ Dr. Dipak K. Sah, \\ E-mail: dipak_ssmc_2003@yahoo.com
}

Copyright: () the author(s), publisher and licensee Medip Academy. This is an open-access article distributed under the terms of the Creative Commons Attribution Non-Commercial License, which permits unrestricted non-commercial use, distribution, and reproduction in any medium, provided the original work is properly cited.

\section{ABSTRACT}

Background: Pre-eclampsia (PE) complicates $2 \%$ of pregnancies and may have serious effects on mother and child, which makes it an important threat to public health in both developed and developing countries. Once high-risk women are identified, they can be targeted for more intense prenatal surveillance and preventative measures. Predicting PE in the first trimester requires the use of maternal echocardiography and the uterine artery pulsatility index (UAPI). Objective of the study was to see whether maternal echocardiography and uterine artery Doppler at 11-14 weeks can predict subsequent development of PE in nulliparous women.

Methods: This prospective observational cohort study was carried out in outdoor patients of obstetrics and gynecology of Bangabandhu Sheikh Mujib Medical University (BSMMU), with collaboration with department of cardiology, National Institute of Nuclear Medicine and Allied Sciences (NINMAS), BSMMU, Dhaka, during 01 December 2013 to July 2015. A total of 135 healthy nulliparous women at 11-14 weeks of gestation were included in this study. Data was processed and analyzed by statistical package for the social sciences (SPSS) version 24.0.

Results: Among 135 patients, two (1.5\%) patients developed preeclampsia during $1^{\text {st }}$ follow-up (20-28 weeks) and four (2.9\%) patients developed preeclampsia during (29-36 weeks). Mean total peripheral resistance was found to be $1332.0 \pm 75.2$ dynes $/ \mathrm{sec} / \mathrm{cm}^{5}$ in preeclampsia and $1157.0 \pm 139.2 \mathrm{dynes} / \mathrm{sec} / \mathrm{cm}^{5}$ in non preeclamptic pregnancy. The difference between two groups was statistically significant. MAP and total peripheral resistance were statistically significant $(\mathrm{p}<0.05)$ between two groups.

Conclusions: In first trimester of pregnancy UAPI is the best predictor for detection of PE.

Keywords: Pregnancies, Echocardiography, Uterine artery Doppler, Pre-eclampsia, Nulliparous

\section{INTRODUCTION}

Preeclampsia (PE) is defined as a multisystem disorder of pregnancy which is characterized by new onset hypertension (systolic and diastolic blood pressure $\geq 140$ and $\geq 90 \mathrm{~mm}$ of $\mathrm{Hg}$, respectively, on two occasions, at least 6 hours apart) and proteinuria (protein excretion $\geq 300 \mathrm{mg}$ in a 24 hour urine collection, or dipstick test $\geq 2+$ ) that develop after 20 weeks of gestation in a previously normotensive and non-protenuric patient. ${ }^{1}$ In recent articles PE are also defined as a syndrome where new onset of hypertension in the second half pregnancy that is generally, but not always, accompanied by proteinuria. ${ }^{2}$ In these cases thrombocytopenia, impaired liver function, new onset of renal insufficiency, pulmonary edema, or new development of cerebral or visual disturbances are considered for diagnosis. Preeclampsia (PE), which affects $2 \%$ of pregnancy, is a major cause of maternal and perinatal morbidity and mortality. ${ }^{3}$ Average incidence of $\mathrm{PE}$ in Bangladesh is $8.22 \%$ of pregnancies. ${ }^{4}$ Accurate PE 
statistics are difficult to obtain because the condition ranges from extremely mild to severe, and mild cases are sometimes not included in the official figures. PE is much more common in first pregnancies and there is a reduced incidence of $\mathrm{PE}$ in the second pregnancy. ${ }^{5,6}$ The traditional method of screening for PE is maternal history. The likely hood of developing PE increases in black, nulliparous, high body mass index (BMI) and previous history or family history of PE. ${ }^{7}$ Pregnancy is characterized by certain structural and functional changes in the cardiovascular systems that are necessary to accommodate the growing demands of the fetus and placenta. ${ }^{8}$ During normal pregnancy mean arterial pressure and vascular resistance decrease, while blood volume and basal metabolic rate increase resulting in increased cardiac output.

A wide range of homodynamic conditions have been described in preeclampsia with no agreement as to the overall cardiac function. There are studies that have reported that women with severe PE have lower cardiac outputs than healthy pregnant women and also studies that show preservation of left ventricular systolic function at term in women with PE. ${ }^{9,10}$ The hypothesis that preeclampsia may be a hyperdynamic state prior to diagnosis is supported by studies by Easterling and Bosio. ${ }^{11}$ These studies demonstrate that there may be a greater rise in cardiac output prior to clinical manifestations of PE than the cardiac output rise that may occur in healthy women. ${ }^{12}$ Adequate cardiovascular adaptation during early pregnancy leads to a state of high blood flow and low vascular resistance, which is a prerequisite to successful pregnancy outcome. In contrast, inadequate or excessive cardiovascular adaptation before 20 weeks gestation is associated with pregnancies complicated by gestational hypertension and PE, and fetal growth restriction (FGR). ${ }^{13}$ Numerous studies reported the hemodynamic findings in patients with established PE, however, and the results were inconsistent. Some studies found a hyperdynamic state characterized by high cardiac output (CO) and low systemic vascular resistance (SVR) whereas others found a hypodynamic state characterized by low CO and elevated SVR. ${ }^{13,14}$ An initial drop characterizes maternal cardiovascular adaptation during pregnancy in peripheral resistance followed by intravascular space expansion and an increase in cardiac output, due to an increase in both stroke volume and heart rate. These changes reach their maximum level at about mid-pregnancy, and are followed by a progressive increase in peripheral resistance and a mild reduction in systolic and diastolic function of the left ventricle (LV) towards term. ${ }^{15}$ Recently, more attention has been paid to the interaction between maternal cardiovascular adaptation and pregnancy complications. PE and FGR have been shown to have distinct patterns of maternal cardiac changes in pregnancy, with worsening maternal cardiac function as the diseases progress. ${ }^{13,14}$

Echocardiography found to be a useful technique for evaluation of maternal cardiac function in preeclamptic women. In PE, there is high $\mathrm{CO}$ and high vascular resistance state. ${ }^{16} \mathrm{PE}$ and intrauterine growth restriction is characterized by abnormal placenta formation which results in inadequate uteroplacental blood flow. ${ }^{17}$ This has led to the idea of using Doppler ultrasonography to assess the velocity of uterine artery blood flow as part of routine ultrasound screening. ${ }^{18}$ Low end-diastolic velocities and an early diastolic notch characterize the waveforms of uterine artery blood flow in women who are not pregnant or are in their first trimester. ${ }^{19}$ There is no proven effective method for the prevention of PE; routine prenatal care in the last 50 years has evolved with the aim of early identification of women at high risk for PE. PE is a progressive condition in pregnancy without any definitive curative management. In recent years, management of PE is directed to prediction, risk detection, early diagnosis and prevention of complications. Many studies were conducted to determine a cardiac function and maternal echocardiography can be used for earliest detection of risk of preeclampsia. There is evidenced that, in a high proportion of pregnancy destined to develop PE, maternal mean arterial pressure and uterine artery pulsatality index (UAPI) are increased at 11-13 weeks of gestation. ${ }^{20}$

In this prospective observational study, maternal echocardiography and uterine artery Doppler were performed in 11 to 14 weeks of gestation and relationship with the development of PE was searched.

\section{Objectives}

The aim of the study was to see whether maternal echocardiography and uterine artery Doppler at 11-14 weeks can predict subsequent development of PE in nulliparous women. Objectives include: to determine the maternal cardiac function by doing echocardiography, cardiac output (CO), stroke volume (SV), mean arterial pressure (MAP), total vascular resistance (TVR), at 11-14 weeks of gestation; to find out UAPI by same period of gestation; to follow these women to detect maternal adverse outcome; to determine the correlation of maternal cardiac function and UAPI with PE; and to find out specificity and sensitivity positive predictive value and negative predictive value of parameter of cardiac function and UAPI.

\section{METHODS}

This prospective observational cohort study was carried out in outdoor patients of obstetrics and gynecology of Bangabandhu Sheikh Mujib Medical University (BSMMU), with collaboration with Department of Cardiology, National Institute of Nuclear Medicine and Allied sciences (NINMAS), BSMMU, Dhaka, during 01 December 2013 to July 2015. A total of 135 healthy nulliparous women at 11-14 weeks of gestation were included in this study. Maternal echocardiography and uterine artery Doppler were performed for measurement of $\mathrm{SV}$, mitral valve annulus shortening, transmitral A-wave and transmitral E-wave and pulsatility index. Then the 
subjects were followed up monthly up to 28 weeks, then two weekly up to 36 weeks than weekly up to term. Inclusion criteria were - age: 18-35 years, gestational stage: 11-14 weeks and healthy nulliparous women with known LMP. Exclusion criteria were women with twin pregnancy, women with heart disease, women with systemic lupus erythematosus (SLE), women with chronic renal disease, chromosomal or suspected ultrasound fetal abnormalities, women with diabetes mellitus and chronic hypertension. At each visit, they were clinically evaluated by measuring blood pressure and testing urine for protein by dipistic method. Data was processed and analyzed by statistical package for the social sciences (SPSS) version 24.0 .

\section{RESULTS}

Baseline parameters of the patients, it was observed that the mean age of the patients was found to be 23.4 \pm 3.4 years with range 18 to 33 years. Mean BMI was found $20.1 \pm 1.6 \mathrm{~kg} / \mathrm{m}^{2}$ with range 16.8 to $22.9 \mathrm{~kg} / \mathrm{m}^{2}$. Mean gestational age was primary enrollment was $12.7 \pm 0.8$ weeks with range 11-14 weeks. The results were shown in the Table 1. During primary enrollment at 11-14 weeks of gestation, Mean MAP was found to be $82.5 \pm 8.4 \mathrm{mmHg}$ with range from 66.7 to $96.7 \mathrm{mmHg}$. Mean total peripheral resistance was found to be $1181.0 \pm 147.7 \mathrm{dynes} / \mathrm{sec} / \mathrm{cm}^{5}$ with range from 926 to 1534 dynes $/ \mathrm{sec} / \mathrm{cm}^{5}$. Mean stroke volume was found to be $67.1 \pm 5.8 \mathrm{ml}$ with range from 60 to $85 \mathrm{ml}$. Mean cardiac output was found to be $5.6 \pm 0.4$ $1 / \mathrm{min}$ with range from 4.9 to $6.4 \mathrm{l} / \mathrm{min}$. The results were shown in the Table 2. $1.5 \%$ (2) of the patients developed PE between 20-28 weeks and six $(2.96 \%)$ patients between 29-36 weeks. Total 4.4\% of the total patients developed PE. The subjects who developed PE had higher SBP, DPB, MAP, TPR, stroke volume, cardiac output and UAPI at baseline (11-14 weeks). Mean MAP was found to be $91.8 \pm 6.5 \mathrm{mmHg} \mathrm{PE}$ and $81.2 \pm 7.8 \mathrm{mmHg}$ in nonpreeclamptic pregnancy. Mean total peripheral resistance was found to be $1332.0 \pm 75.2$ dynes $/ \mathrm{sec} / \mathrm{cm}^{5}$ in PE and $1157.0 \pm 139.2$ dynes $/ \mathrm{sec} / \mathrm{cm}^{5}$ in non-preeclamptic pregnancy. Mean stroke volume was found to be 68.0 \pm 4.7 $\mathrm{ml}$ in $\mathrm{PE} 67.3 \pm 5.8 \mathrm{ml}$ in non-preeclamptic pregnancy. Mean cardiac output was found to be $5.6 \pm 0.41 / \mathrm{min}$ in PE and $5.3 \pm 0.31 / \mathrm{min}$ in non-preeclamptic pregnancy. Mean UAPI was found $1.22 \pm 0.35 \mathrm{l} / \mathrm{min}$ in PE, $1.93 \pm 0.46 \mathrm{l} / \mathrm{min}$ $\mathrm{PE}$ and $1.06 \pm 0.27 \mathrm{l} / \mathrm{min}$ in non-preeclamptic pregnancy. Receiver-operator characteristic (ROC) curve of MAP, stroke volume, MVAS and cardiac output for prediction of PE. The area under the ROC curves for the predictor of PE is depicted in the following table. Based on the ROC curves MAP had the best area under curve compared to stroke volume and cardiac output. ROC were constructed using MAP value of the women, which gave a MAP cut off value of $\geq 75$ as the value with a best combination of sensitivity and specificity for PE. ROC curve of UAPI and total peripheral resistance for prediction of PE. Based on the ROC curves UAPI had the best area under curve. ROC were constructed UAPI of the women, which gave UAPI cut off value of as the value 1.01 with a best combination of sensitivity and specificity for PE.

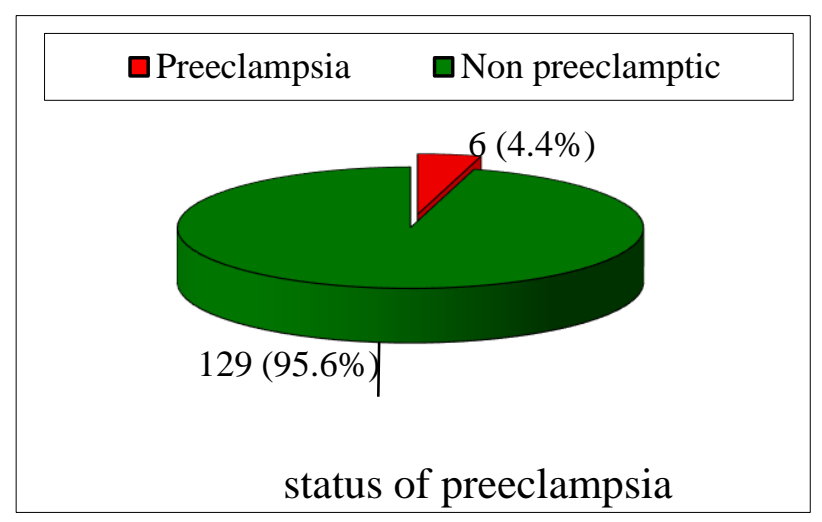

Figure 1: The status of PE.

Table 1: Demographic characteristic of the study population at baseline parameters (age, BMI and gestational age $)(n=135)$.

\begin{tabular}{|lcll|}
\hline Age (in year) & $\mathbf{n = 1 3 5}$ & $\%$ & $\begin{array}{l}\text { Range } \\
\text { (min-max) }\end{array}$ \\
\hline$\leq 20$ & 20 & 14.8 & $18-33$ \\
\hline $21-25$ & 49 & 36.3 & \\
\hline $26-30$ & 50 & 37.0 & \\
\hline$>30$ & 16 & 11.9 & \\
\hline Mean \pm SD & 23.4 & \pm 3.4 & \\
\hline BMI $\left(\mathbf{k g} / \mathbf{m}^{\mathbf{2}}\right)$ & & & \\
\hline$<18.5$ & 13 & 9.6 & $16.8-22.9$ \\
\hline $18.5-23$ & 122 & 90.4 & \\
\hline Mean \pm SD & 20.1 & \pm 1.6 & \\
\hline Gestational age (weeks) & & \\
\hline Mean \pm SD & 12.7 & \pm 0.8 & $11-14$ \\
\hline
\end{tabular}

Table 2: MAP, total peripheral resistance, stroke volume and cardiac output at baseline at 11-14 weeks of gestation $(n=135)$.

\begin{tabular}{|lll|}
\hline Parameters & Mean \pm SD & Min, max \\
\hline MAP (mmHg) & $82.5 \pm 8.4$ & $66.7,96.7$ \\
\hline $\begin{array}{l}\text { Total peripheral } \\
\text { resistance (dynes/sec/cm }\end{array}$ & $1181.0 \pm 14$ & \\
\hline Stroke volume $(\mathbf{m l})$ & 67.7 & 926,1534 \\
\hline Cardiac output $(\mathbf{l} / \mathbf{m i n})$ & $5.6 \pm 0.4$ & $4.9,6.4$ \\
\hline
\end{tabular}

Table 3: MVAS, transmitral E-wave velocity and transmitral A-wave velocity levels in study subjects $(n=135)$.

\begin{tabular}{|lll|}
\hline Parameters & Mean \pm SD & Min, max \\
\hline $\begin{array}{l}\text { Mitral valve annulus } \\
\text { shortening (mm) }\end{array}$ & $1.76 \pm 0.08$ & $1.6,1.9$ \\
\hline $\begin{array}{l}\text { Transmtiral E-wave } \\
\text { velocity (m/sec) }\end{array}$ & $0.75 \pm 0.28$ & $0.01,1.82$ \\
\hline $\begin{array}{l}\text { Transmitral A-wave } \\
\text { velocity (m/sec) }\end{array}$ & $0.67 \pm 0.31$ & $0.01,1.26$ \\
\hline
\end{tabular}




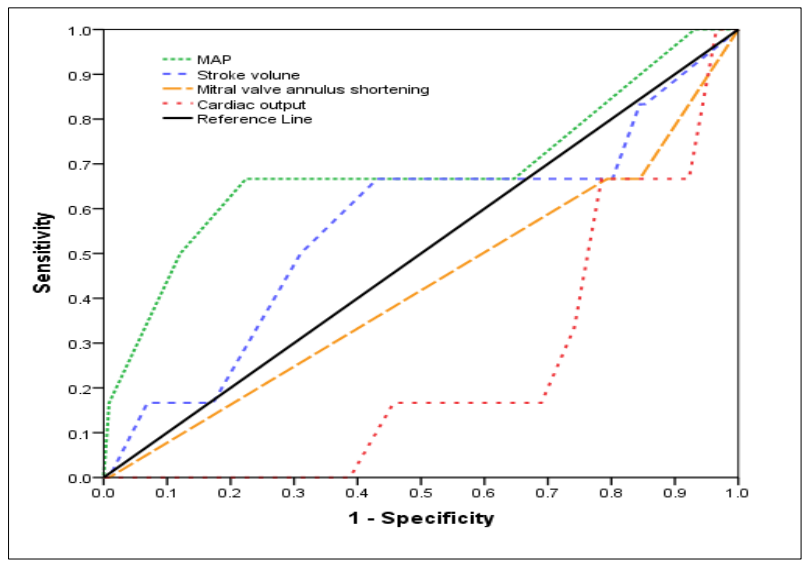

Figure 2: ROC curves of MAP, stroke volume, MVAS and cardiac output.

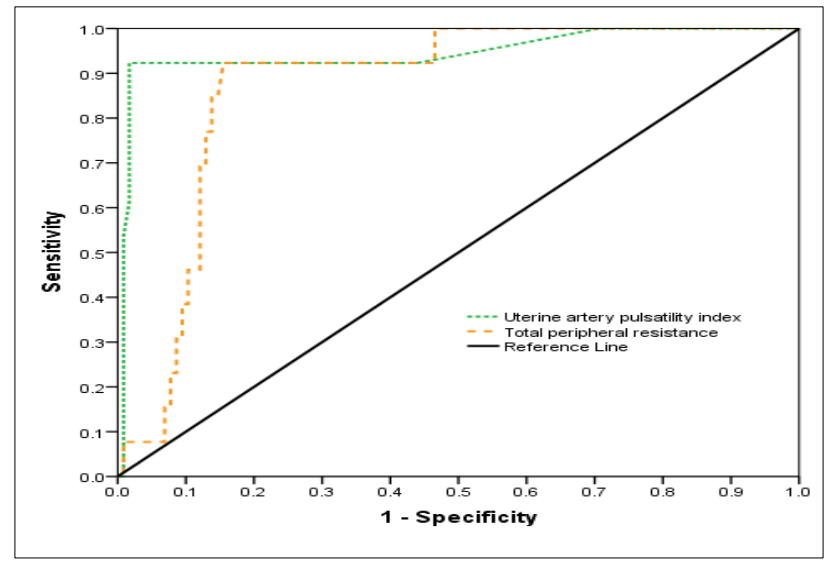

Fig 3: ROC curves of UAPI and total peripheral resistance.

Table 4: UAPI levels in study subjects $(n=135)$.

Parameter

Uterine artery pulsatility index
$1.15 \pm 0.39$
Min, max

$0.15,3.49$

Table 5: Change in blood pressure in different follow up of study subjects $(n=135)$.

\begin{tabular}{|c|c|c|c|c|}
\hline Blood pressure & $\begin{array}{l}\text { Primary enrolment } \\
\text { (11-14 weeks) n (\%) }\end{array}$ & $\begin{array}{l}\text { 1st follow up } \\
(>20 \text { to } \leq 28 \text { weeks) n ( } \%)\end{array}$ & $\begin{array}{l}\text { Last follow up } \\
(<36 \text { weeks) } \mathbf{n}(\%)\end{array}$ & P value \\
\hline \multicolumn{5}{|c|}{ Systolic BP (mmHg) } \\
\hline$<140$ (normal) & $135(100.0)$ & $133(98.5)$ & $129(95.6)$ & \multirow{4}{*}{$0.001 \mathrm{~s}$} \\
\hline$\geq 140$ & $0(0.0)$ & $2(1.5)$ & $6(4.4)$ & \\
\hline Mean \pm SD & $117.3 \pm 9.7$ & $121.7 \pm 11.3$ & $127.6 \pm 19.7$ & \\
\hline Range (min, max) & 100,135 & 100,210 & 100,220 & \\
\hline \multicolumn{5}{|c|}{ Diastolic BP (mmHg) } \\
\hline$<90$ (normal) & $135(100.0)$ & $133(98.5)$ & $129(95.6)$ & \multirow{4}{*}{$0.001 \mathrm{~s}$} \\
\hline$\geq 90$ & $0(0.0)$ & $2(1.5)$ & $6(4.4)$ & \\
\hline Mean \pm SD & $65.4 \pm 6.6$ & $69.3 \pm 8.2$ & $72.7 \pm 13.1$ & \\
\hline Range (min, max) & 55,80 & 60,110 & 60,120 & \\
\hline
\end{tabular}

Table 6: Distribution of the patients by dipstick proteinuria $(n=135)$.

\begin{tabular}{|c|c|c|c|c|c|}
\hline $\begin{array}{l}\text { Dipstick } \\
\text { proteinuria }\end{array}$ & $\begin{array}{l}\text { Primary enrolment } \\
\text { (11-14 weeks) n (\%) }\end{array}$ & $\begin{array}{l}1^{\text {st }} \text { follow up } \\
(>20 \text { to } \leq 28 \text { weeks) } n(\%)\end{array}$ & $\begin{array}{l}\text { Last follow up } \\
\text { (<36 weeks) n }(\%)\end{array}$ & $\begin{array}{l}Z \\
\text { value }\end{array}$ & $P$ value \\
\hline Positive & $0(0.0)$ & $2(1.5)$ & $6(4.4)$ & & \multirow{2}{*}{$<0.001$} \\
\hline Negative & $135(100.0)$ & $133(98.5)$ & $129(95.6)$ & 4.71 & \\
\hline
\end{tabular}

Table 7: MAP, total peripheral resistance, stroke volume and cardiac output levels in preeclampsia and nonpreeclamptic pregnancy $(\mathbf{n}=\mathbf{1 3 5})$.

\begin{tabular}{|c|c|c|c|c|c|}
\hline \multirow{2}{*}{ Parameters } & \multicolumn{2}{|c|}{ Preeclampsia $(n=6)$} & \multicolumn{2}{|c|}{ Non-preeclamptic $(\mathrm{n}=129)$} & \multirow[t]{2}{*}{ P value } \\
\hline & Mean & \pm SD & Mean & \pm SD & \\
\hline SBP $(m m H g)$ & 116 & \pm 11.5 & 104 & \pm 14.5 & \multirow{2}{*}{$0.048^{\mathrm{s}}$} \\
\hline Range (min, max) & 111.0 & 127.5 & 100.0 & 118.5 & \\
\hline DBP (mmHg) & 72.0 & \pm 5.5 & 60.0 & \pm 10.0 & \multirow{2}{*}{$0.042^{\mathrm{s}}$} \\
\hline Range (min, max) & 66 & 77.5 & 54.0 & 70.0 & \\
\hline MAP (mmHg) & 91.8 & \pm 6.5 & 81.2 & \pm 7.8 & \multirow{2}{*}{$0.001^{\mathrm{s}}$} \\
\hline Range (min, max) & 73.3 & 96.7 & 66.7 & 96.7 & \\
\hline TPR (dynes/sec/cm ${ }^{5}$ ) & 1332.0 & \pm 75.2 & 1157.0 & \pm 139.2 & \multirow{2}{*}{$0.028^{\mathrm{s}}$} \\
\hline Range (min, max) & 1164 & 1481 & 926 & 1534 & \\
\hline
\end{tabular}




\begin{tabular}{|c|c|c|c|c|c|}
\hline \multirow{2}{*}{ Parameters } & \multicolumn{2}{|c|}{ Preeclampsia $(n=6)$} & \multicolumn{2}{|c|}{ Non-preeclamptic $(\mathrm{n}=129)$} & \multirow[t]{2}{*}{ P value } \\
\hline & Mean & \pm SD & Mean & \pm SD & \\
\hline Stroke volume (ml) & 68.0 & \pm 4.7 & 67.3 & \pm 5.8 & \multirow{2}{*}{$0.341^{\mathrm{ns}}$} \\
\hline Range (min, max) & 60 & 75 & 60 & 85 & \\
\hline Cardiac output (1/min) & 5.6 & \pm 0.3 & 5.3 & \pm 0.3 & \multirow{2}{*}{$0.018^{\mathrm{s}}$} \\
\hline Range (min, max) & 5 & 6 & 5 & 5.8 & \\
\hline Uterine artery pulsatility index & 1.93 & \pm 0.46 & 1.06 & \pm 0.27 & \multirow{2}{*}{$0.001^{\mathrm{s}}$} \\
\hline Range (min, max) & 1 & 2.5 & 0.15 & 3.49 & \\
\hline
\end{tabular}

Table 8: MVAS, transmiral-E wave velocity and transmiral-A wave velocity levels in preeclampsia, and nonpreeclamptic pregnancy $(\mathbf{n}=\mathbf{1 3 5})$.

\begin{tabular}{|c|c|c|c|c|c|}
\hline \multirow{2}{*}{ Parameters } & \multicolumn{2}{|c|}{ Preeclampsia $(n=6)$} & \multicolumn{2}{|c|}{ Non-preeclamptic ( $\mathrm{n}=129)$} & \multirow[t]{2}{*}{ P value } \\
\hline & Mean & $\pm \mathrm{SD}$ & Mean & \pm SD & \\
\hline Mitral valve annulus shortening (mm) & 1.76 & \pm 0.07 & 1.73 & \pm 0.1 & $0.469^{\text {ns }}$ \\
\hline Range (min, max) & 1.6 & 1.9 & 1.6 & 1.8 & \multirow{2}{*}{$0.052^{\mathrm{ns}}$} \\
\hline Transmiral-E wave velocity $(\mathrm{cm} / \mathrm{sec})$ & 0.93 & \pm 0.53 & 0.72 & \pm 0.24 & \\
\hline Range (min, max) & 0.31 & 1.82 & 0.01 & 1.32 & \multirow{3}{*}{$0.198^{\mathrm{ns}}$} \\
\hline Transmiral-A wave velocity $(\mathrm{cm} / \mathrm{sec})$ & 0.82 & \pm 0.14 & 0.65 & \pm 0.32 & \\
\hline Range (min, max) & 0.54 & 0.95 & 0.01 & 1.26 & \\
\hline
\end{tabular}

Table 9: ROC curve of MAP, stroke volume, MVAS and cardiac output for prediction of preeclampsia.

\begin{tabular}{|llllllllll|}
\hline & $\begin{array}{l}\text { Cut } \\
\text { of } \\
\text { value }\end{array}$ & $\begin{array}{l}\text { Sensiti- } \\
\text { vity } \\
(\%)\end{array}$ & $\begin{array}{l}\text { Specific- } \\
\text { ity }(\%)\end{array}$ & $\begin{array}{l}\text { Accur- } \\
\text { acy }(\%)\end{array}$ & $\begin{array}{l}\text { PPV } \\
(\%)\end{array}$ & $\begin{array}{l}\text { NPV } \\
(\%)\end{array}$ & $\begin{array}{l}\text { Area under } \\
\text { the ROC } \\
\text { curve }\end{array}$ & $\begin{array}{l}\text { 95\% confidence } \\
\text { interval (CI) }\end{array}$ \\
\hline MAPer $(\mathbf{m m H g})$ & 75 & 66.7 & 35.3 & 37.8 & 5.1 & 94.6 & 0.686 & $\begin{array}{l}\text { Upper } \\
\text { bound } \\
\text { bound }\end{array}$ \\
\hline $\begin{array}{l}\text { Stroke volume } \\
\text { (m) }\end{array}$ & 63 & 66.7 & 19.8 & 20.9 & 4.1 & 92.0 & 0.560 & 0.409 & 0.964 \\
\hline $\begin{array}{l}\text { Cardiac output } \\
\text { (l/min) }\end{array}$ & 5.35 & 33.3 & 25.9 & 26.2 & 2.3 & 88.2 & 0.241 & 0.09 & 0.825 \\
\hline
\end{tabular}

Table 10: ROC curve of UAPI and TPR for prediction of preeclampsia.

\begin{tabular}{|llllllllll|}
\hline & $\begin{array}{l}\text { Cut } \\
\text { of } \\
\text { value }\end{array}$ & $\begin{array}{l}\text { Sensiti- } \\
\text { vity } \\
(\%)\end{array}$ & $\begin{array}{l}\text { Specific- } \\
\text { ity }(\%)\end{array}$ & $\begin{array}{l}\text { Accur- } \\
\text { acy }(\%)\end{array}$ & $\begin{array}{l}\text { PPV } \\
(\%)\end{array}$ & $\begin{array}{l}\text { NPV } \\
(\%)\end{array}$ & $\begin{array}{l}\text { Area under } \\
\text { the ROC } \\
\text { curve }\end{array}$ & $\begin{array}{l}\text { 95\% confidence } \\
\text { interval (CI) }\end{array}$ \\
\begin{tabular}{lllllllll|} 
Lower \\
bound
\end{tabular} & $\begin{array}{l}\text { Upper } \\
\text { bound }\end{array}$ \\
\hline $\begin{array}{l}\text { Uterine artery } \\
\text { pulsatility index }\end{array}$ & 1.01 & 92.3 & 56.0 & 59.7 & 19.0 & 98.5 & 0.945 & 0.860 & 1.00 \\
\hline $\begin{array}{l}\text { Total peripheral } \\
\text { resistance }\end{array}$ & 1284 & 84.6 & 85.6 & 85.5 & 39.3 & 98.0 & 0.870 & 0.796 & 0.945 \\
\hline
\end{tabular}

\section{DISCUSSION}

$\mathrm{PE}$ is not a uniformly high-resistance, volume contracted state as previously thought. ${ }^{21}$ Earlier studies, using direct haemodynamic measurements in women with severe preeclampsia requiring invasive monitoring, have described variations in haemodynamic characteristics ranging from a hyperdynamic state with a higher-than-normal cardiac output and increased left ventricular function to a vasoconstrictive state with decreased $\mathrm{CO}$ and diminished left ventricular function. These studies also document variable systemic resistance profiles, ranging from normal- to high resistance states. ${ }^{22,23}$ However, since the introduction and evaluation of the Doppler technique for maternal cardiac function in pregnancy a series of echocardiograph studies have confirmed the existence of haemodynamic alterations in women with overt or preclinical PE. ${ }^{13}$ These studies have advocated a maternal hyperdynamic circulation that is preceding the clinically overt disease and may also be present to a variable degree during the more severe stages. ${ }^{14}$

In this study $1.5 \%$ (2) of the patients developed PE between 20-28 weeks and six (2.96\%) patients between 29-36 weeks. Total $4.4 \%$ of the total patients developed PE. Mean SBP was found to be $117.3 \pm 9.7 \mathrm{mmHg}$ in baseline parameter, $121.7 \pm 11.3 \mathrm{mmHg}$ in $1^{\text {st }}$ follow up and 127.6 $\pm 19.7 \mathrm{mmHg}$ in last follow up. Mean DBP was found 
$65.4 \pm 6.6 \mathrm{mmHg}$ in baseline data, $69.3 \pm 8.2 \mathrm{mmHg}$ in $1^{\text {st }}$ follow up and $72.7 \pm 13.1 \mathrm{mmHg}$ in last follow up. It was observed that two $(1.5 \%)$ patients were had dipstick proteinuria in $1^{\text {st }}$ follow up and $6(4.4 \%)$ in last follow up including first follow up. In this study it was observed that $6(4.4 \%)$ patients had PE. Average proportion of PE among hospital admission varies from $7.5-8.5 \%$ as same mentioned by Shamsuddin et al, and Salako et al found PE $9.7 \%$ in their study patients, which is comparable with the current study. In another study Martin et al found PE was $2.1 \%$ in their study, which is less than the current study. ${ }^{27}$

Khaw et al found that the mean SBP was $116 \mathrm{mmHg}$ in PE group and $104 \mathrm{mmHg}$ in normal pregnancy group. Mean DBP was found $72 \mathrm{mmHg}$ in PE group and $60 \mathrm{mmHg}$ in normal pregnancy group. Mean MAP was found 90.0 $\mathrm{mmHg}$ in PE group and $77.3 \mathrm{mmHg}$ in normal pregnancy group. Mean stroke volume was found $87.9 \pm 15.2 \mathrm{ml}$ in PE group and $64.0 \pm 11.7 \mathrm{ml}$ in normal pregnancy group. In another study Rao et al found the mean arterial pressure was $118 \mathrm{~mm}$ of $\mathrm{Hg}$ in cases and $87 \mathrm{~mm}$ of $\mathrm{Hg}$ in controls. Rizwana et al in their study found that the differences in systolic BP, diastolic BP and MAP were statistically significant between two groups. MAP of the PE was $115.88 \pm 9.87$, higher than that of controls $(83.85 \pm 5.71)$. Cardiac output in the preeclamptic group was $66.85 \pm 4.56$ $\mathrm{ml} / \mathrm{min}$ as compared to $56.1 \pm 1.77 \mathrm{ml} / \mathrm{min}$ in the normotensive group. This observation was statistically significant at $(\mathrm{p}<0.05)$. Bosio et al (1999) and Easterling et al also found similar findings in their study.

Khaw et al observed the mean mitral valve annulus shortening $(\mathrm{mm}) 15.5 \pm 2.0 \mathrm{~mm}$ in normal, $17.8 \pm 1.7 \mathrm{~mm}$ in PE. ${ }^{27}$ The mean transmitral E-wave velocity $82.4 \pm 13.6$ $\mathrm{mm} / \mathrm{sec}$ in normal, $95.7 \pm 14.6 \mathrm{~mm} / \mathrm{sec}$ in $\mathrm{PE}$ which is similar with the current study. These changes begin early in pregnancy, reach their peak during the second trimester, and then remain relatively constant until delivery. They contribute to optimal growth and development of the fetus. $^{28}$

In this study it was observed that based on the ROC curves MAP had the best area under curve compared to stroke volume, MVAS and cardiac output. ROC were constructed using MAP value of the women, which gave a MAP cut off value of $\geq 75$ as the value with a combination of sensitivity $66.7 \%$ and specificity $35.3 \%$ for PE, stroke volume cut off value of $>63 \mathrm{ml}$ having $66.7 \%$ sensitivity, $19.8 \%$ specificity, MVAS cut off value of $>1.75 \mathrm{~mm}$ having $66.7 \%$ sensitivity, $20.7 \%$ specificity and cardiac output cut off value of $>5.351 / \mathrm{mm}$ having $33.3 \%$ sensitivity, $25.9 \%$ specificity. An UAPI cut off value of $>1.01$ as the value with a best combination of $92.3 \%$ sensitivity and $56.0 \%$ specificity and total peripheral resistance cut off value of $>1284$ having $84.6 \%$ sensitivity and $85.6 \%$ specificity. Khaw et al found that the best point on the ROC curve for prediction of PE by UAPI was at the probability of more than $5.4 \%$ with a sensitivity of $77.8 \%$, specificity of $79.1 \%$ and a screen-positive rate of $20.0 \%$.
Compared with the non-preeclamptic group in those who developed PE, CO, MAP, TPR, SV and UAPI were increased. Based on ROC curve best predictor for PE was UAPI.

\section{Limitations}

The present study was conducted in a very short period due to time constraints and funding limitations. The small sample size was also a limitation of the present study.

\section{CONCLUSION}

The result of my study showed that estimation of maternal cardiac function and/or UAPI early in the first trimester of pregnancy are/is of value in prediciting subsequent development of PE. However, UAPI is the best predictor for detection of PE.

\section{Recommendations}

A large population and multicentre study is recommended to properly define the value of estimation of maternal echocardiography and uterine artery Doppler in early pregnancy in the prediction of either.

Funding: No funding sources Conflict of interest: None declared

Ethical approval: The study was approved by the Institutional Ethics Committee

\section{REFERENCES}

1. Sibai B, Dekker G, Kupferminc M. Pre-eclampsia. The Lancet. 2005;365(9461):785-99.

2. Pettit F, Brown MA. The management of preeclampsia: what we think we know. Eur J Obstet Gynecol Reprod Biol. 2012;160(1):6-12.

3. World Health Organization. Make every mother and child count: World Health Day, 7 April 2005: a toolkit for organizers of activities. 2005. Available at: https://www.google.com/url?sa=t\&rct=j\&q=\&esrc=s $\&$ source $=$ web $\& c d=\& c a d=r j a \& u a c t=8 \& v e d=2 a h U K$ EwihooGwu_n0AhXJldgFHXuzD8YQFnoECAoQA Q\&url=https $\% 3 \mathrm{~A} \% 2 \mathrm{~F} \% 2 \mathrm{Fapps}$. who.int $\% 2$ Firis $\% 2 \mathrm{~F}$ handle\%2F10665\%2F68863\&usg=AOvVaw3T9x_T 24Eruq8Cy-FbpXdI. Accessed on 03 August 2021.

4. Begum A. Study on clinical profile and outcome of preeclampsia. Dissertation, Bangladesh College of physician and surgeon. 2004.

5. Bhattacharyya SK, Kundu S, Kabiraj SP. Prediction of preeclampsia by midtrimester uterine artery Doppler velocimetry in high-risk and low-risk women. J Obstet Gynecol India. 2012;62(3):297-300.

6. McDonald SD, Lutsiv O, Dzaja N, Duley L. A systematic review of maternal and infant outcomes following magnesium sulfate for preeclampsia/eclampsia in real-world use. Int J Gynecol Obstet. 2012;118(2):90-6. 
7. Ck Y, Smith GC, Papageorghiou AT, Cacho AM, Nicolaides KH, Fetal Medicine Foundation Second Trimester screening Group. An integrated model for the prediction of preeclampsia using maternal factors and uterine artery Doppler velocimetry in unselected low-risk women. Am J Obstet Gynecol. 2005;193(2):429-36.

8. Plasencia W, Maiz N, Bonino S, Kaihura C, Nicolaides KH. Uterine artery Doppler at $11+0$ to $13+$ 6 weeks in the prediction of pre-eclampsia. Ultrasound Obstet Gynecol. 2007;30(5):742-9.

9. Lewis G. Confidential Enquiry Into Maternal and Child Health: Saving Mother's Lives: Reviewing Maternal Deaths to Make Motherhood Safer-20032005: Executive Summary and Key Recommendations: December 2007. CEMACH. 2007.

10. Schlembach D. Pre-eclampsia-still a disease of theories. Fukushima J Med Sci. 2003;49(2):69-115.

11. Luo ZC, An N, Xu HR, Larante A, Audibert F, Fraser WD. The effects and mechanisms of primiparity on the risk of pre-eclampsia: a systematic review. Paediatric Perinatal Epidemiol. 2007;21:36-45.

12. Bellamy L, Casas JP, Hingorani AD, Williams DJ. Pre-eclampsia and risk of cardiovascular disease and cancer in later life: systematic review and metaanalysis. BMJ. 2007;335(7627):974.

13. Bosio PM, McKenna PJ, Conroy R, O’Herlihy C. Maternal central hemodynamics in hypertensive disorders of pregnancy. Obstet Gynecol. 1999;94(6):978-84.

14. Easterling TR, Benedetti TJ, Schmucker BC, Millard SP. Maternal hemodynamics in normal and preeclamptic pregnancies: a longitudinal study. Obstet Gynecol. 1990;76(6):1061-9.

15. Xiong X, Demianczuk NN, Saunders LD, Wang FL, Fraser WD. Impact of preeclampsia and gestational hypertension on birth weight by gestational age. Am J Epidemiol. 2002;155(3):203-9.

16. Solanki R, Maitra N. Echocardiographic assessment of cardiovascular hemodynamics in preeclampsia. J Obstet Gynecol India. 2011;61(5):519-22.

17. Khong TY, De Wolf F, Robertson WB, Brosens I. Inadequate maternal vascular response to placentation in pregnancies complicated by pre-eclampsia and by small-for-gestational age infants. BJOG. 1986;93(10):1049-59.
18. Steel SA, Pearce JM, Chamberlain GV. Doppler ultrasound of the uteroplacental circulation as a screening test for severe pre-eclampsia with intrauterine growth retardation. Eur J Obstet Gynecol Reprod Biol. 1988;28(4):279-87.

19. Bolte AC, Dekker GA. Uterine artery Doppler as screening tool for preeclampsia. When to screen in obstetrics and gynecology. Philadelphia: Saunders Elsevier. 2006;408-19.

20. Poon LC, Kametas NA, Maiz N, Akolekar R, Nicolaides KH. First-trimester prediction of hypertensive disorders in pregnancy. Hypertension. 2009;53(5):812-8.

21. Visser W, Wallenburg HC. Central hemodynamic observations in untreated preeclamptic patients. Hypertension. 1991;17(6):1072-7.

22. Mabie WC, Ratts TE, Sibai BM. The central hemodynamics of severe preeclampsia. Am J Obstet Gynecol. 1989;161(6):1443-8.

23. Phelan JP, Yurth DA. Severe preeclampsia: I. Peripartum hemodynamic observations. Am J Obstet Gynecol. 1982;144(1):17-22.

24. Martin PY. Mobilizing masculinities': women's experiences of men at. Organization. 2001;8(4):587618.

25. Turan JM, Miller S, Bukusi EA, Sande J, Cohen CR. HIV/AIDS and maternity care in Kenya: how fears of stigma and discrimination affect uptake and provision of labor and delivery services. AIDS Care. 2008;20(8):938-45.

26. Salako BL, Olayemi O, Odukogbe AT, Adedapo KS, Aimakhu CO, Alu FE, Ola B. Microalbuminuria in pregnancy as a predictor of preeclampsia and eclampsia. West Af J Med. 2003;22(4):295-300.

27. Khaw KT, Wareham N, Bingham S, Welch A, Luben R, Day N. Combined impact of health behaviours and mortality in men and women: the EPIC-Norfolk prospective population study. PLoS Med. 2008;5(1):12.

28. Hunter S, Robson SC. Adaptation of the maternal heart in pregnancy. Br Heart J. 1992;68(6):540.

Cite this article as: Sah DK, Deeba F, Chowdhury $\mathrm{SB}$. The role of maternal echocardiography and uterine artery Doppler at 11-14 weeks in the prediction of pre-eclampsia in nulliparous women. Int J Reprod Contracept Obstet Gynecol 2022;11:24-30. 